Opinion

\title{
Ecocultural or Biocultural? Towards Appropriate Terminologies in Biocultural Diversity
}

\author{
F. Merlin Franco (D)
}

check for updates

Citation: Franco, F.M. Ecocultural or Biocultural? Towards Appropriate Terminologies in Biocultural Diversity. Biology 2022, 11, 207. https://doi.org/10.3390/ biology11020207

Academic Editors: Sun Hee Woo and Andrea Pieroni

Received: 29 November 2021

Accepted: 17 January 2022

Published: 28 January 2022

Publisher's Note: MDPI stays neutral with regard to jurisdictional claims in published maps and institutional affiliations.

Copyright: (C) 2022 by the author. Licensee MDPI, Basel, Switzerland. This article is an open access article distributed under the terms and conditions of the Creative Commons Attribution (CC BY) license (https:// creativecommons.org/licenses/by/ $4.0 /)$.
Institute of Asian Studies, Universiti Brunei Darussalam, Gadong BE1410, Brunei; merlin.francis@ubd.edu.bn

Simple Summary: Biocultural diversity espouses an inseparable link between biological, cultural, and linguistic diversity. Biocultural diversity is not alone in using the term 'biocultural'. The term has been used in biocultural studies within anthropology decades ahead of biocultural studies. Both biocultural studies and biocultural diversity use the term 'biocultural' as adjective to generate new terminologies such as 'biocultural approach' with varying connotations. Such a confusing scenario might hinder theoretical advancements in biocultural diversity. Hence, I propose that proponents of biocultural diversity explore possibilities of adapting the term 'ecoculture' from cultural studies. Perhaps using the term 'ecocultural' instead of 'biocultural' as a descriptor to coin terminologies could solve confusions arising from the expanding usage of the term 'bioculture'.

\begin{abstract}
Biocultural diversity has made notable contributions that have furthered our understanding of the human culture-nature interrelationship. However, the usage of the term 'biocultural' is not unique to biocultural diversity. It was first used in biocultural studies within anthropology decades ahead of biocultural diversity. The existing literature on biocultural diversity does not acknowledge the prior existence of biocultural studies, or provide a clear demarcation between usages of the two terms. In this article, I discuss the varying contexts in usage of the term 'biocultural' between biocultural diversity and biocultural anthropology. While biocultural diversity deals with the linkages between biological, cultural, and linguistic diversity, biocultural studies in anthropology deal with the deterministic influence of physical and social environment on human biology and wellbeing. In biocultural studies, 'biocultural' refers to the integration of methodically collated cultural data with biological and environmental data. 'Bio' in biocultural anthropology therefore denotes biology, unlike biocultural diversity where it refers to biodiversity. Both biocultural studies and biocultural diversity apply 'biocultural' as descriptor to generate overlapping terminologies such as 'biocultural approach'. Such a confusing scenario is not in the interest of biocultural diversity, as it would impede theoretical advancements. I propose that advocates of biocultural diversity explore its harmonies with ecoculturalism and the possibilities of suitably adapting the term 'ecoculture' in lieu of 'bioculture'. Using 'ecocultural' instead of 'biocultural' as a descriptor to coin terminologies could solve confusions arising from the expanding usage of the term 'bioculture'.
\end{abstract}

Keywords: biocultural diversity; biocultural anthropology; biocultural studies; ecocultural studies; cultural studies; ecoculture; cultural diversity; environment; probabilism; environmental studies

\section{Introduction}

Biocultural diversity is the diversity of life in all of its manifestations: biological, cultural, and linguistic, which are interrelated (and possibly coevolved) within a complex socio-ecological adaptive system [1] (p. 269). The origin of the concept of biocultural diversity could be traced back to 1988, when 'The Declaration of Belém' from the First International Congress of Ethnobiology recognized an 'inextricable link' between biological and cultural diversity [2]. By recognizing cultural diversity, biocultural diversity offers a better approach to understand the interrelationships between humans and nature [3]. In recent years, there has also been an emphasis on the dynamic, reciprocal nature of 
the human culture-nature relationship [4]. The accordance of prominence to cultural and linguistic diversities distinguishes biocultural diversity from biodiversity (or biological diversity) defined as the "variety and variability among living organisms and the ecological complexes in which they occur" [5] (see also [6,7]). Biodiversity with its species conservation-oriented approach excluded local people and their interrelationship with nature. Anthropologists helped in bridging the gap between biodiversity conservation and local communities [8], while the definition of biodiversity also evolved to accommodate cultural diversity [9]. However, biodiversity falls short of the holistic approach towards the human culture-language-biodiversity complex advocated by biocultural diversity. The number of publications using the biocultural diversity framework has been growing since the 2000s [3,10]. As outlined by Luisa Maffi [3], these studies tend to have four major foci: (i) the relationship between language, traditional knowledge, and the environment; (ii) common threats to biological, cultural, and linguistic diversities; (iii) conservation and revitalization of biocultural diversity; and (iv) biocultural diversity and human rights.

Maffi describes biocultural diversity as a 'multifaceted field of research' in her landmark publications that provide the theoretical underpinnings of this area of study $[1,3]$. Some academics (especially ethnobiologists) approach it as a conceptual framework that bridges the nature-culture divide [11]. However, biocultural diversity is not alone in using the term 'biocultural'. The term 'biocultural' was first used in biocultural studies within anthropology, whose origin can be traced to the 1960s (decades ahead of biocultural diversity) [12-14]. Biocultural studies in anthropology deal with the influence of biological and cultural environment on human biology and wellbeing [15]. Biocultural diversity on the other hand, deals with the linkages between biological, cultural, and linguistic diversities. Although biocultural diversity has accumulated a significant volume of literature since the 2000s [10], the current literature on biocultural diversity does not acknowledge the prior existence of biocultural studies in anthropology or provide a clear demarcation between the two concepts. Maffi's article published in the Annual Review of Anthropology in 2005 [3], a reputed journal in the field of anthropology, misses the opportunity to provide a clear demarcation between the two paradigms. Such a scenario creates confusion in the minds of young anthropologists and ethnobiologists getting acquainted with the term 'biocultural'. Clarity at the level of definitions and usage of appropriate terminologies are quintessential for theoretical advancements in any field of enquiry [16]. Therefore, in this article, I discuss the different contexts in usage of the term 'biocultural' as a descriptor in biocultural diversity and biocultural studies within anthropology. I highlight the confusion caused by the usage of the same term in diverging contexts by both the paradigms. Lastly, I conclude by proposing that the term 'ecocultural' is a better alternative to use as a descriptor in studies using the biocultural diversity framework.

\section{Biocultural Studies in Anthropology}

The origins of biocultural studies within anthropology could be traced to 1930s when anthropologists including W. Montague Cobb studied the influence of social environments on human health [17]. In the 1960s, specific research methods in biocultural studies were advanced by the International Biological Program [18]. However, specific usage of the term only appears in the 1970s [19]. There are considerable variations in the conceptualization of biocultural studies, with some anthropologists nesting it within biological anthropology and others explicitly advocating biocultural anthropology as a sub-discipline of biological anthropology $[12,19,20]$. Given the variations in conceptualizations, there have been calls to focus on what biocultural studies does in the contemporary world, rather than its definition [21]. Prior to 1998, biocultural approaches in anthropology aimed to understand the deterministic pathways by which social, economic, cultural, and ecological factors influence human biology and wellbeing $[12,13,15]$. Biocultural studies has evolved since then to emphasize reciprocity in human-environment relationship, with the conceptualization of the field expanded to encompass human niche construction [21]. However, the deterministic influence of biological and cultural factors on human biology and wellbeing, 
especially the study of human physiological and cultural adaptation to environmental conditions [20], continues to be the major focus of the field [22]. Biocultural studies within the realm of biological anthropology and associated fields see humans as 'biological, social, and cultural beings' [12], and the discipline has strong synergies to medical anthropology, ecological anthropology, and political economy [21,22]. A small number of studies also tend to employ evolutionary theory or political economic analyses [19]. Various associations of anthropology have organized conferences in biocultural studies/anthropology, and a plethora of articles have also been published in leading journals in anthropology [19,23].

\section{'Biocultural' in Biocultural Studies}

The coining of the term 'biocultural' is believed to be the result of anthropology's quest for turning into a holistic field [19,24]. According to Ann McElroy [12], the ideal sense of 'biocultural' in biocultural studies is the integration of methodically collated cultural data with biological and environmental data. The 'bio' in biocultural studies therefore denotes biology. There appears to be little consensus on the usage of the term within biocultural studies, or a theoretical framework that outlines the constitutive elements and processes. In their bibliometric review, Wiley and Cullin found tremendous variation in its usage [19]. In the majority of studies, the term implies the influence of social environment on human biology. However, there were 180 terms formed using 'biocultural' as a descriptor (adjective) often with little clarity on what they intend to convey. In Table 1, I provide subjective examples of variations in direct usage of the term 'biocultural' in biocultural studies. In these examples, 'biocultural' has been combined with terms such as 'adaptation' and 'approach' to produce varying connotations. Notable usage includes 'biocultural diversity/variations' to denote morphological variations in human populations, induced by cultural practices such as intentional body modification practices [25].

Table 1. Examples of terms coined using 'biocultural' as descriptor in biocultural studies.

\begin{tabular}{|c|c|}
\hline Terminology & Usage \\
\hline Biocultural adaptation & Influence of environment and lifestyle on human physiology $[26,27]$. \\
\hline Biocultural analyses/perspectives & $\begin{array}{l}\text { Linking culture and biology to unravel how biological phenomena such as birth are affected } \\
\text { by cultural interpretations and practices [28]. }\end{array}$ \\
\hline Biocultural approach & $\begin{array}{l}\text { Environment influencing obesity and nutritional status [29]. } \\
\text { "Humans as biological, social and cultural beings in relation to the environment" McElroy } \\
\text { [12] cited in Khongsdier [30]. }\end{array}$ \\
\hline Biocultural diversity/variations & $\begin{array}{l}\text { Human morphological variations induced by diverse range of intentional body } \\
\text { modification practices [25]. }\end{array}$ \\
\hline Biocultural evolution & Evolution of biological and cultural characteristics [31]. \\
\hline Biocultural model & $\begin{array}{l}\text { A model that could be useful in "conceptualizing the complex interaction of biological, } \\
\text { cultural and psychosocial factors in the process of human pain perception" [32]. }\end{array}$ \\
\hline Biocultural predictors & Combination of biological and cultural factors [33]. \\
\hline Bio-cultural sciences & $\begin{array}{l}\text { "Bio-cultural sciences highlight the notion that human behaviour is the joint and } \\
\text { co-constructive expression of biological-genetic and cultural-societal processes and } \\
\text { conditions." [34] }\end{array}$ \\
\hline Biocultural studies & $\begin{array}{l}\text { "Questions of human biology and medical ecology that specifically include social, cultural, } \\
\text { or behavioural variables in the research design" [12]. }\end{array}$ \\
\hline Biocultures & $\begin{array}{l}\text { Re-thinking of culture and history by considering their 'inextricable' relationship with } \\
\text { biology [35]. } \\
\text { "Cultural spheres where biomedicine extends beyond the formal institutions of the clinic, } \\
\text { the hospital, the lab, and so forth and is incorporated into broader social practices and } \\
\text { rationalities" [36]. }\end{array}$ \\
\hline
\end{tabular}

Note: For a comprehensive list of descriptors published between 2000 and 2014, see Wiley and Cullin [19]. 


\section{3. 'Biocultural' in Biocultural Diversity: Similar Terminologies, but Confounding Usage}

Biocultural diversity deals with the inextricable linkages between biological, cultural, and linguistic diversities $[1,3,37,38]$. It thus focuses on the manifestation of these diversities, and not the influence of cultural and social environment on human biology advocated by biocultural studies [12]. The 'bio' in biocultural diversity therefore refers to biodiversity and not biology as in biocultural studies. According to Mercon et al. [39], the term 'bioculture' is employed in biocultural diversity "to emphasize tightly intertwined and co-evolving socialecological systems, cultural dimensions and implications in such systems". A subjective scan of published academic literature shows an overlap in terminologies coined by applying the term 'biocultural' as descriptor between both the paradigms, with the context of its usage in biocultural diversity being different from biocultural studies in anthropology (Tables 1 and 2). A 'biocultural approach' in the latter could mean understanding the influence of environment on human health by examining parameters such as obesity and nutritional status [29], while in biocultural diversity it would mean an approach that recognizes the co-existence of biological and cultural diversity, and the linkages between them $[39,40]$. If biocultural conservation in biocultural diversity means to conserve biological and cultural diversity [41], in the context of biocultural studies it would mean conserving the diverse patterns of environmental influence on human wellbeing when applied. Thus, the possibilities to generate various terminologies incorporating 'biocultural' in both biocultural studies and biocultural diversity are innumerable, leading to a confusing scenario, a complexity that would only grow from here unless resolved. Such a confusing scenario is further exemplified by the usage of 'biocultural diversity' as such in biocultural studies to refer to morphological variations in human populations [25].

Table 2. Examples of terms coined using 'biocultural' as descriptor in biocultural diversity.

\begin{tabular}{|c|c|}
\hline Terminology & Usage \\
\hline Biocultural approach & $\begin{array}{l}\text { Recognising human beings and non-humans as co-habitants of ecosystems [42,43]. } \\
\text { "Biocultural approaches are an emergent area of study that conceptualize } \\
\text { interrelationships between cultures and the environment" [40]. }\end{array}$ \\
\hline Biocultural approaches to conservation & $\begin{array}{c}\text { "Conservation actions made in the service of sustaining the biophysical and } \\
\text { sociocultural components of dynamic, interacting, and interdependent } \\
\text { social-ecological systems" [41] }\end{array}$ \\
\hline Biocultural characteristics & Undefined [44]. \\
\hline Biocultural conservation & Stemming the dual loss of biological and cultural diversity [41]. \\
\hline Biocultural design & $\begin{array}{l}\text { "People are creative agents with knowledge, values and skills that allow them to } \\
\text { shape their everyday lives" [45] }\end{array}$ \\
\hline Biocultural ethics & $\begin{array}{l}\text { "Recovering the vital links between biological and cultural diversity, between the } \\
\text { habits and the habitats of the inhabitants" [46]. }\end{array}$ \\
\hline Biocultural heritage & Biodiversity and culture as heritage [47]. \\
\hline Biocultural homogenization & $\begin{array}{l}\text { "Simultaneous and interdigitated losses of native biological and cultural diversity at } \\
\text { local, regional, and global scales" [46]. }\end{array}$ \\
\hline Biocultural importance & Biological and cultural importance of plants, animals and landscapes $[48,49]$. \\
\hline Biocultural indicators & $\begin{array}{l}\text { Foreseeable seasonal events such as flowering of calendar plants that are culturally } \\
\text { significant to local communities [50]. }\end{array}$ \\
\hline Biocultural interactions & Interactions between local people and ecosystems [51]. \\
\hline Biocultural landscape & $\begin{array}{c}\text { Landscapes that integrate "economic, social, cultural and environmental processes in } \\
\text { time and space" [52]. }\end{array}$ \\
\hline Biocultural learning & $\begin{array}{l}\text { "Learning complexity in and about nature, particularly to the dimensions and } \\
\text { processes involved when people have nature as a workplace" [53]. }\end{array}$ \\
\hline
\end{tabular}


Table 2. Cont.

\begin{tabular}{cc}
\hline Terminology & Usage \\
\hline Biocultural memory & $\begin{array}{r}\text { "The human memory is the result of interactions between biological and cultural traits, } \\
\text { considered as biocultural memory" [54]. }\end{array}$ \\
\hline Biocultural refugia/Bio-cultural refugia & $\begin{array}{c}\text { "Physical places that not only shelter farm biodiversity, but also carry knowledge and } \\
\text { experiences about practical management of how to produce food while stewarding } \\
\text { biodiversity and ecosystem services" [55]. }\end{array}$ \\
\hline Biocultural systems & $\begin{array}{c}\text { Systems moulded jointly by biological and cultural forces [38]. } \\
\text { Biocultures }\end{array}$ \\
\hline "Allective biocultural heritage & $\begin{array}{c}\text { "Knowledge, innovations and practices of indigenous and local communities which } \\
\text { are collectively held and inextricably linked to traditional resources and territories, } \\
\text { local economies, the diversity of genes, varieties, species and ecosystems, cultural and } \\
\text { spiritual values, and customary laws shaped within the socio-ecological context of } \\
\text { communities" [57] }\end{array}$ \\
\hline Indigenous biocultural Knowledge & $\begin{array}{r}\text { "Knowledge that encompasses people, language } \\
\text { and culture and their relationship to the environment" [58] }\end{array}$ \\
\hline
\end{tabular}

Of the articles published in AAA journals during the 2000-2014 period, Wiley and Cullin found 3\% to use the term 'biocultural' [19]. These usages are in a context different from that of biocultural diversity, except for those explicitly dealing with biocultural diversity. Although the authors recognize that biocultural diversity is distinct from biocultural studies/anthropology, they call upon academics to explore ways to harmonize these two paradigms. However, the differences between biocultural studies in anthropology and biocultural diversity are vast to reconcile. If biocultural studies in anthropology are concerned with the influence of biological and cultural factors on human biology and health, then biocultural diversity is about "the living network made up of the millions of species and animals and the thousands of human culture and languages that have evolved on earth" [59]. The conceptualization of biocultural studies in anthropology has been expanded recently to emphasize the reciprocal relationship between humans and nature [21], marking a conscientious shift from environmental determinism to environmental probabilism (See: Lewthwaite [60]). However, it is undeniable that the core area of focus has been human health and wellbeing, especially the deterministic impact of social and physical environment on human health $[19,22]$. Contrarily, from its inception, biocultural diversity has recognized the ever-evolving complex and reciprocal interaction between nature and humans, thus assuming a probabilistic stand [1,11]. Furthermore, biocultural diversity does not focus on the influence of the physical and biological environments on human biology and health.

The evident divergence in conceptualization of 'biocultural', and its confounding usages in biocultural studies and biocultural diversity is unaffordable in academia. In an era where keywords increasingly play an important role in access to knowledge [61], young anthropologists, ethnobiologists, linguists, or geographers undertaking literature review would invariably be confused in the diverse usages. Of the 199 articles tagged with 'biocultural' in the Scopus database for the year 2020 (Supplementary Materials File S1), the majority $(n=122)$ have used the biocultural diversity framework, while the remaining were from biocultural studies. Although this indicates the increasing popularity and acceptability of biocultural diversity among researchers probing the human-nature nexus, it also points out the confusing scenario in the usage of 'bioculture/biocultural'. Indeed, as the younger of the two paradigms, the onus is on biocultural diversity to differentiate itself from biocultural studies. A radical step here is to debate the possibility of re-branding biocultural diversity as ecocultural diversity. However, this would require serious effort in building consensus among advocates of biocultural diversity. A more acceptable middle-path could be to retain biocultural diversity as such at the conceptual level but to use 'ecocultural' instead of 'biocultural' as descriptor. Thus, the term 'biocultural approach' in biocultural 
diversity would become 'ecocultural approach' instead, 'biocultural revitalization' would become 'ecocultural revitalization', and so on $[62,63]$.

\section{The Need for Considering 'Ecoculture' in Biocultural Diversity}

The term 'ecoculture' is popular in cultural studies, environmental communication, and psychology where it signifies the reciprocal and inseparable link between ecology and culture [62,64-66], a paradigm referred to as 'ecoculturalism' [67]. An ecoculturalist perspective advocates that sociocultural identity is inseparable from ecology [68]. It also recognizes that local knowledge and memories of the dynamic link between the non-human component of landscapes and human culture shape ecocultural identities and promote resilience [69-71]. In tourism, ecoculturalism offers an opportunity to appreciate both the cultural and ecological aspects of destinations [72]. Like biocultural diversity, ecoculturalism also recognizes that ecological crises leads to cultural crises [70]. Meanwhile in cultural studies, it has also been hotly debated if the term ecoculturalism should be abandoned, as the field of cultural studies addresses the nature-culture dualism adequately [67,73]. Bohm et al. [74] refer to those communities living an ecocultural lifestyle that recognizes, demonstrates, and nurtures the deep linkages between social and ecological environments as 'ecocultures' — an application that is similar to 'biocultures' in biocultural diversity [56] but different from 'biocultures' as used in biocultural studies $[35,36,75]$. Ecocultures or ecocultural communities appreciate the reciprocal relationship between nature and culture, the need for nurturing ecosystem health, recognition of all lifeforms as sentient beings, and the importance of a healthy nature-culture relationship [76-79]. These communities are characterized by ethical principles that prioritize the nurturing of sociological and ecological wellbeing, recognize that wellbeing does not constitute of economic wellbeing alone, consider humans as a part of nature, and strive to conserve and sustain natural, human and social capitals [74,80]. The usage of the term 'ecocultural' in cultural studies, psychology and elsewhere, and 'biocultural' in biocultural diversity are remarkably similar as they both recognize the inextricable link between ecosystems and culture [37]. Given that the term 'biocultural' has been used in a different context in biocultural studies within anthropology long before the birth of biocultural diversity, it is in the interest of the latter to suitably adapt the term 'ecoculture' to distinguish its program from that of biocultural studies in anthropology.

\section{Conclusions}

Biocultural studies within anthropology originated decades ahead of biocultural diversity. Modern conceptualizations of biocultural studies have expanded its scope to include reciprocity in human-environment relationships. Yet, the deterministic influence of physical and social environment on human health and wellbeing continues to be the major focus of the field. 'Bio' in biocultural studies refers to human biology, while 'biocultural' refers to the integration of methodically collated cultural data with biological and environmental data. In biocultural diversity, 'bio' refers to biodiversity, and 'biocultural' refers to the co-evolving biological and cultural diversity and the linkages between them. Biocultural diversity is a well-defined paradigm with a robust theoretical framework. From its inception, the paradigm has espoused a probabilistic relationship between biological, linguistic, and cultural diversity. However, the usage of 'biocultural' in a context differing from that of biocultural studies has led to a confusing scenario with overlapping terminologies such as 'biocultural approach', coined in biocultural studies, and biocultural diversity, with varying connotations. The scenario could become more confounding in the future, with the emergence of the usage of 'biocultural diversity' as such in biocultural studies in a context other than that of biocultural diversity. Being the younger of the two paradigms, the onus is on biocultural diversity to demarcate itself from biocultural studies and steer itself clear of confusing terminologies. I propose that advocates of biocultural diversity explore its harmonies with ecoculturalism and the possibilities of suitably adapting the term 'ecoculture' in lieu of 'biocultural'. Using 'ecocultural' instead of 'biocultural' as descriptor to coin 
terminologies could solve much of the confusions arising from the expanding usage of the term 'biocultural'.

Supplementary Materials: The following are available online at https:/ /www.mdpi.com/article/10 $.3390 /$ biology11020207/s1. File S1: Publications tagged with 'biocultural' in the Scopus database for the year 2020.

Funding: This research received no external funding.

Institutional Review Board Statement: Not applicable.

Informed Consent Statement: Not applicable.

Data Availability Statement: Data supporting reported results can be found in the Supplementary File S1.

Acknowledgments: The author expresses his sincere gratitude to Abey P. Philip of Curtin University Malaysia for all help received.

Conflicts of Interest: The author declares no conflict of interest.

\section{References}

1. Maffi, L. Biocultural diversity and sustainability. In The Sage Handbook of Environment and Society; Pretty, J., Ball, A., Benton, T., Guivant, J., Lee, D., Orr, D., Pfeffer, M., Ward, H., Eds.; SAGE Publications Ltd: London, UK, 2007; pp. $267-277$.

2. International Society of Ethnobiology the Declaration of Belem. Available online: https://www.ethnobiology.net/what-we-do/ core-programs/global-coalition-2/declaration-of-belem/ (accessed on 11 September 2021).

3. Maffi, L. Linguistic, Cultural, and Biological Diversity. Annu. Rev. Anthropol. 2005, 34, 599-617. [CrossRef]

4. Cocks, M.; Wiersum, F. Reappraising the Concept of Biocultural Diversity: A Perspective from South Africa. Hum. Ecol. 2014, 42, 727-737. [CrossRef]

5. Office of Technology Assessment. Technologies to Maintain Biological Diversity; U.S. Government Printing Office: Washington, DC, USA, 1987.

6. Swingland, I.R. Biodiversity, Definition of. In Encyclopedia of Biodiversity; Elsevier: San Diego, CA, USA, 2001 ; pp. $377-391$.

7. Delong, D. Defining Biodiversity. Wildl. Soc. Bull. 1996, 24, 738-749.

8. Orlove, B.S.; Brush, S.B. Anthropology and the conservation of biodiversity. Annu. Rev. Anthropol. 1996, 25, 329-352. [CrossRef]

9. Heywood, V. (Ed.) The Global Biodiversity Assessment; Cambridge University Press: Cambridge, UK, 1995.

10. Hidayati, S.; Franco, F.M.; Bussmann, R.W. Ready for phase 5-Current status of ethnobiology in Southeast Asia. J. Ethnobiol. Ethnomed. 2015, 11, 17. [CrossRef] [PubMed]

11. Franco, F.M.; Knudsen, M.; Hassan, N.H. (Eds.) Chapter Case Studies in Biocultural Diversity from Southeast Asia-Traditional Ecological Calendars, Folk Medicine and Folk Names. In Case Studies in Biocultural Diversity from Southeast Asia: Traditional Ecological Calendars, Folk Medicine and Folk Names; Springer: Singapore, 2022.

12. McElroy, A. Biocultural Models in Studies of Human Health and Adaptation. Med. Anthropol. Q. 1990, 4, 243-265. [CrossRef]

13. Alland, A., Jr. Medical Anthropology and the Study of Biological and Cultural Adaptation. Am. Anthropol. 1966, 68, 40-51. [CrossRef]

14. Zuckerman, M.K.; Martin, D.L. (Eds.) Introduction: The development of biocultural perspectives in anthropology. In New Directions in Biocultural Anthropology; John Wiley \& Sons, Inc.: Hoboken, NJ, USA, 2016; pp. 7-26.

15. Leonard, W.R. Re-examining Biocultural Approaches in Human Biology. Am. J. Hum. Biol. 2020, 32, e23475. [CrossRef]

16. Segraves, B.A. Ecological Generalization and Structural Transformation of Sociocultural Systems. Am. Anthropol. 1974, 76, 530-552. [CrossRef]

17. Watkins Rachel, J. Knowledge from the Margins: W. Montague Cobb's Pioneering Research in Biocultural Anthropology. Am. Anthropol. 2007, 109, 186-196. [CrossRef]

18. Little, A.M.; Dyson-Hudson, N.; Dyson-Hudson, R.; Ellis, E.J.; Swift, D.M. Human biology and the development of an ecosystem approach. In The Ecosystem Concept in Anthropology; Moran, E.F., Ed.; Westview Press: Boulder, CO, USA, $1984 ;$ pp. $103-132$.

19. Wiley, A.S.; Cullin, J.M. What Do Anthropologists Mean When They Use the Term Biocultural? Am. Anthropol. 2016, 118, 554-569. [CrossRef]

20. Ulijaszek, S. Biological and Biocultural Anthropology. In When Culture Impacts Health: Global Lessons for Effective Health Research; Banwell, C., Ulijaszek, S., Dixon, J., Eds.; Academic Press: Oxford, UK, 2013; pp. 23-31.

21. Hoke, M.K.; Schell, L.M. Doing biocultural anthropology: Continuity and change. Am. J. Hum. Biol. 2020, 32, e23471. [CrossRef] [PubMed]

22. Leatherman, T.; Goodman, A. Building on the biocultural syntheses: 20 years and still expanding. Am. J. Hum. Biol. 2020, 32, e23360. [CrossRef] [PubMed] 
23. Willermet, C. Biological Anthropology in 2015: Open Access, Biocultural Interactions, and Social Change. Am. Anthropol. 2016, 118, 317-329. [CrossRef]

24. Calcagno, M.J. Keeping Biological Anthropology in Anthropology, and Anthropology in Biology. Am. Anthropol. 2003, 105, 6-15. [CrossRef]

25. Willman, J.C.; Hernando, R.; Matu, M.; Crevecoeur, I. Biocultural diversity in Late Pleistocene/Early Holocene Africa: Olduvai Hominid 1 (Tanzania) biological affinity and intentional body modification. Am. J. Phys. Anthropol. 2020, 172, 664-681. [CrossRef]

26. Goodman, A.H.; Brooke Thomas, R.; Swedlund, A.C.; Armelagos, G.J. Biocultural perspectives on stress in prehistoric, historical, and contemporary population research. Am. J. Phys. Anthropol. 1988, 31, 169-202. [CrossRef]

27. Baker, P.T. Human Adaptation to High Altitude. Science 1969, 163, 1149-1156. [CrossRef]

28. Stone, P.K. Biocultural perspectives on maternal mortality and obstetrical death from the past to the present. Am. J. Phys. Anthropol. 2016, 159, 150-171. [CrossRef]

29. Crooks, D.L. Trading Nutrition for Education: Nutritional Status and the Sale of Snack Foods in an Eastern Kentucky School. Med. Anthropol. Q. 2003, 17, 182-199. [CrossRef]

30. Khongsdier, R. Bio-cultural Approach: The Essence of Anthropological Study in the 21st Century. Anthropol. Spec. Vol. 2007, 3, 39-50.

31. Msaidie, S.; Ducourneau, A.; Boetsch, G.; Longepied, G.; Papa, K.; Allibert, C.; Yahaya, A.A.; Chiaroni, J.; Mitchell, M.J. Genetic diversity on the Comoros Islands shows early seafaring as major determinant of human biocultural evolution in the Western Indian Ocean. Eur. J. Hum. Genet. 2011, 19, 89-94. [CrossRef] [PubMed]

32. Bates, M.S.; Edwards, T.W.; Anderson, K.O. Ethnocultural influences on variation in chronic pain perception. Pain 1993, 52, 101-112. [CrossRef]

33. Luz, L.G.O.; Valente-dos-Santos, J.; Luz, T.D.D.; Sousa-e-Silva, P.; Duarte, J.P.; Machado-Rodrigues, A.; Seabra, A.; Santos, R.; Cumming, S.P.; Coelho-e-Silva, M.J. Biocultural Predictors of Motor Coordination Among Prepubertal Boys and Girls. Percept. Mot. Skills 2018, 125, 21-39. [CrossRef] [PubMed]

34. Baltes, P.B.; Singer, T. Plasticity and the ageing mind: An exemplar of the bio-cultural orchestration of brain and behaviour. Eur. Rev. 2001, 9, 59-76. [CrossRef]

35. Davis, L.J.; Morris, D.B. Biocultures Manifesto. New Lit. Hist. 2007, 38, 411-418. [CrossRef]

36. Ehlers, N.; Krupar, S. (Eds.) Introduction: Biocultures. In Deadly Biocultures: The Ethics of Life-Making; The University of Minnesota Press: Minneapolis, MN, USA, 2019.

37. Pretty, J.; Adams, B.; Berkes, F.; de Athayde, S.; Dudley, N.; Hunn, E.; Maffi, L.; Milton, K.; Rapport, D.; Robbins, P.; et al. The intersections of biological diversity and cultural diversity: Towards integration. Conserv. Soc. 2009, 7, 100-112. [CrossRef]

38. Maffi, L. Maintaining and Restoring Biocultural Diversity: The Evolution of a Role for Ethnobiology. Adv. Econ. Bot. 2004, 15, 9-35.

39. Merçon, J.; Vetter, S.; Tengö, M.; Cocks, M.; Balvanera, P.; Rosell, J.A.; Ayala-Orozco, B. From local landscapes to international policy: Contributions of the biocultural paradigm to global sustainability. Glob. Sustain. 2019, 2, e7. [CrossRef]

40. Baumflek, M.; Kassam, K.-A.; Ginger, C.; Emery, M.R. Incorporating Biocultural Approaches in Forest Management: Insights from a Case Study of Indigenous Plant Stewardship in Maine, USA and New Brunswick, Canada. Soc. Nat. Resour. 2021, 34, 1155-1173. [CrossRef]

41. Gavin, M.C.; McCarter, J.; Mead, A.; Berkes, F.; Stepp, J.R.; Peterson, D.; Tang, R. Defining biocultural approaches to conservation. Trends Ecol. Evol. 2015, 30, 140-145. [CrossRef]

42. Santafe-Troncoso, V.; Loring, P.A. Traditional food or biocultural threat? Concerns about the use of tilapia fish in Indigenous cuisine in the Amazonia of Ecuador. People Nat. 2021, 3, 887-900. [CrossRef]

43. Rozzi, R. Biocultural ethics: From biocultural homogenization to biocultural conservation. In Linking Ecology and Ethics for a Changing World: Values, Philosophy, and Action; Rozzi, R., Pickett, T., Palmer, C., Armesto, J.J., Callicott, J., Eds.; Springer: Dordrecht, The Netherlands, 2013; pp. 9-32.

44. Frainer, A.; Mustonen, T.; Hugu, S.; Andreeva, T.; Arttijeff, E.-M.; Arttijeff, I.-S.; Brizoela, F.; Coelho-de-Souza, G.; Printes, R.B.; Prokhorova, E.; et al. Opinion: Cultural and linguistic diversities are underappreciated pillars of biodiversity. Proc. Natl. Acad. Sci. USA 2020, 117, 26539-26543. [CrossRef] [PubMed]

45. Davidson-Hunt, I.J.; Turner, K.L.; Mead, A.T.P.; Cabrera-Lopez, J.; Bolton, R.; Idrobo, J.C.; Miretski, I.; Morrison, A.; Robson, J.P. Biocultural design: A new conceptual framework for sustainable development in rural indigenous and local communities. SAPI EN. S Surv. Perspect. Integr. Environ. Soc. 2012, 5, 33-45.

46. Rozzi, R. Biocultural Ethics. Environ. Ethics 2012, 34, 27-50. [CrossRef]

47. Khan, S.; Hussain, W.; Sulaiman; Shah, S.; Hussain, H.; Altyar, A.E.; Ashour, M.L.; Pieroni, A. Overcoming Tribal Boundaries: The Biocultural Heritage of Foraging and Cooking Wild Vegetables among Four Pathan Groups in the Gadoon Valley, NW Pakistan. Biology 2021, 10, 537. [CrossRef]

48. Franco, F.M.; Abdul Ghani, B.A.; Hidayati, S. Biocultural importance of the tanying [Koompassia excelsa (becc.) taub.] tree for the Berawan of Loagan Bunut, Sarawak, Malaysia. Indian J. Tradit. Knowl. 2014, 13, 63-69.

49. Franco, F.M.; Chaw, L.L.; Bakar, N.; Abas, S.N.H. Socialising over fruits and vegetables: The biocultural importance of an open-air market in Bandar Seri Begawan, Brunei Darussalam. J. Ethnobiol. Ethnomed. 2020, 16, 6. [CrossRef] 
50. McKemey, M.; Ens, E.; Rangers, Y.M.; Costello, O.; Reid, N. Indigenous Knowledge and Seasonal Calendar Inform Adaptive Savanna Burning in Northern Australia. Sustainability 2020, 12, 995. [CrossRef]

51. Ojeda, J.; Rozzi, R.; Rosenfeld, S.; Contadora, T.; Massardo, F.; Malebrán, J.; González-Calderón, J.; Mansilla, A. Interacciones bioculturales del pueblo yagán con las macroalgas y moluscos: Una aproximación desde la filosofía ambiental de campo. Magallania (Punta Arenas) 2018, 46, 155-181. [CrossRef]

52. Agnoletti, M.; Rotherham, I.D. Landscape and biocultural diversity. Biodivers. Conserv. 2015, 24, 3155-3165. [CrossRef]

53. Garavito-Bermúdez, D. Biocultural learning-Beyond ecological knowledge transfer. J. Environ. Plan. Manag. 2020, 63, 1791-1810. [CrossRef]

54. Alves de Siqueira, J.I.; Trindade Medeiros, M.F.; de Senna-Valle, L. A methodological proposal for the use of short stories regarding the biocultural memory as a pedagogical tool. Ethnobot. Res. Appl. 2020, 20,1-9. [CrossRef]

55. Barthel, S.; Crumley, C.L.; Svedin, U. Biocultural Refugia: Combating the Erosion of Diversity in Landscapes of Food Production. Ecol. Soc. 2013, 18, art71. [CrossRef]

56. Simberloff, D. Nature, Culture, and Natureculture: The Role of Nonnative Species in Biocultures. In From Biocultural Homogenization to Biocultural Conservation; Rozzi, R., May, R.H., Jr., Chapin, F.S., III, Massardo, F., Gavin, M.C., Klaver, I.J., Pauchard, A., Nunez, M.A., Simberloff, D., Eds.; Springer Nature: Cham, Switzerland, 2018; pp. 207-218.

57. Swiderska, K.; Argumedo, A. Towards a holistic approach to indigenous knowledge protection: UN activities, “Collective Bio-Cultural Heritage" and the UNPFII. In Proceedings of the Fifth Session of the UN Permanent Forum on Indigenous Issues, New York, NY, USA, 15-26 May 2006.

58. Ens, E.J.; Pert, P.; Clarke, P.A.; Budden, M.; Clubb, L.; Doran, B.; Douras, C.; Gaikwad, J.; Gott, B.; Leonard, S.; et al. Indigenous biocultural knowledge in ecosystem science and management: Review and insight from Australia. Biol. Conserv. 2015, 181, 133-149. [CrossRef]

59. Montoya, F.; Dilts, O. Terralingua: Unity in biocultural diversity. Langscape 2013, 2, 3.

60. Lewthwaite, G.R. Environmentalism and Determinism: A search for clarification. Ann. Assoc. Am. Geogr. 1966, 56, 1-23. [CrossRef]

61. Wang, J.; Su, G.; Wan, C.; Huang, X.; Sun, L. A Keyword-Based Literature Review Data Generating Algorithm-Analyzing a Field from Scientific Publications. Symmetry 2020, 12, 903. [CrossRef]

62. Pretty, J. Interdisciplinary progress in approaches to address social-ecological and ecocultural systems. Environ. Conserv. 2011, 38, 127-139. [CrossRef]

63. Pilgrim, S.; Samson, C.; Pretty, J. EcoCultural Revitalisation: Replenishing Community Connections to the Land. In EcoCultural Revitalisation: Replenishing Community Connections to the Land; Pilgrim, S., Pretty, J., Eds.; Earthscan: London, UK, 2010; pp. 235-256.

64. Berry, J.W. An Ecocultural Perspective on the Development of Competence. In Culture and Competence: Contexts of Life Success; Sternberg, R., Grigorenko, E., Eds.; American Psychological Association: Washington, DC, USA, 2004; pp. 3-22.

65. Nsamenang, A.B. Ecocultural Theories of Development. In International Encyclopedia of the Social E Behavioral Sciences; Wright, J., Ed.; Elsevier: Oxford, UK, 2015; Volume 6, pp. 838-844.

66. Chen, Y.-W.; Milstein, T.; Anguiano, C.; Sandoval, J.; Knudsen, L. Challenges and Benefits of Community-Based Participatory Research for Environmental Justice: A Case of Collaboratively Examining Ecocultural Struggles. Environ. Commun. 2012, 6, 403-421. [CrossRef]

67. Daryl Slack, J. Resisting ecocultural studies. Cult. Stud. 2008, 22, 477-497. [CrossRef]

68. Milstein, T.; Castro-Sotomayor, J. (Eds.) Routledge Handbook of Ecocultural Identity; Routledge: London, UK, 2020.

69. Hoffmann, J.A. Memory, Waterways, and Ecocultural Identity. In The Routledge Handbook of Ecocultural Identity; Milstein, T., Castro-Sotomayor, J., Eds.; Routledge: Abingdon, UK, 2020.

70. Dahake, S. The making of fluid ecocultural identities in urban India. In Routledge Handbook of Ecocultural Identity; Milstein, T., Castro-Sotomayor, J., Eds.; Routledge: Abingdon, UK; New York, NY, USA, 2020; pp. 333-350.

71. Zedler, J.B.; Stevens, M.L. Western and Traditional Ecological Knowledge in Ecocultural Restoration. San Fr. Estuary Watershed Sci. 2018, 16, 1-18. [CrossRef]

72. Cajee, L. Eco-Cultural Tourism: A Tool for Environmental, Cultural and Economic Sustainability (A Case Study of Darap Village, West Sikkim). SHS Web Conf. 2014, 12, 01029. [CrossRef]

73. Giblett, R. Nature is ordinary too: Raymond Williams as the founder of ecocultural studies. Cult. Stud. 2012, 26, 922-933. [CrossRef]

74. Böhm, S.; Bharucha, Z.P.; Pretty, J. (Eds.) Ecocultures: Towards sustainable ways of living. In Ecocultures: Blueprints for Sustainable Communities; Routledge: Abingdon, UK, 2015; pp. 3-26.

75. Krupar, S.; Ehlers, N. Biocultures: A critical approach to mundane biomedical governance. Cult. Theory Crit. 2020, 61, 440-456. [CrossRef]

76. Burger, J.; Gochfeld, M.; Pletnikoff, K.; Snigaroff, R.; Snigaroff, D.; Stamm, T. Ecocultural Attributes: Evaluating Ecological Degradation in Terms of Ecological Goods and Services Versus Subsistence and Tribal Values. Risk Anal. 2008, 28, 1261-1272. [CrossRef] [PubMed]

77. Long, J.; Lake, F.K.; Lynn, K.; Viles, C. Tribal ecocultural resources and engagement. In Synthesis of Science to Inform Land Management within the Northwest Forest Plan Area; Spies, T., Stine, P., Gravenmier, R., Long, J., Reilly, M., Eds.; USDA Forest Service, Pacific Northwest Research Station: Portland, OR, USA, 2018; pp. 851-917. 
78. Rapport, D.J.; Maffi, L. Eco-cultural health, global health, and sustainability. Ecol. Res. 2011, 26, 1039-1049. [CrossRef] [PubMed]

79. Ryan, J.C. Passive Flora? Reconsidering Nature's Agency through Human-Plant Studies (HPS). Societies 2012, 2, 101-121. [CrossRef]

80. Yongming, Z. How Our Village Becomes “Ecocultural”. In Cultural Change and Persistence; Ascher, W., Heffron, J., Eds.; Palgrave Macmillan US: New York, NY, USA, 2010; pp. 133-146. 